\title{
NOX REDUCTION WITH NATURAL GAS FOR LEAN LARGE-BORE ENGINE APPLICATIONS USING LEAN NOX TRAP AFTERTREATMENT
}

\author{
James E. Parks II, H. Douglas Ferguson III, John M. E. Storey \\ Oak Ridge National Laboratory, 2360 Cherahala Blvd., Knoxville, TN 37932
}

\begin{abstract}
Large-bore natural gas engines are used for distributed energy and gas compression since natural gas fuel offers a convenient and reliable fuel source via the natural gas pipeline and distribution infrastructure. Lean engines enable better fuel efficiency and lower operating costs; however, NOx emissions from lean engines are difficult to control. Technologies that reduce NOx in lean exhaust are desired to enable broader use of efficient lean engines. Lean NOx trap catalysts have demonstrated greater than $90 \%$ NOx reduction in lean exhaust from engines operating with gasoline, diesel, and natural gas fuels. In addition to the clean nature of the technology, lean NOx traps reduce NOx with the fuel source of the engine thereby eliminating the requirement for storage and handling of secondary fuels or reducing agents. A study of lean NOx trap catalysts for lean natural gas engines is presented here. Testing was performed on a Cummins C8.3G (CG-280) engine on a motor dynamometer. Lean NOx trap catalysts were tested for NOx reduction performance under various engine operating conditions, and the utilization of natural gas as the reductant fuel source was characterized. Engine test results show that temperature greatly affects the catalytic processes involved, specifically methane oxidation and NOx storage on the lean NOx trap. Additional studies on a bench flow reactor demonstrate the effect of precious metal loading (a primary cost factor) on lean NOx trap performance at different temperatures. Results and issues related to the potential of the lean NOx trap technology for large-bore engine applications will be discussed.
\end{abstract}

\section{INTRODUCTION}

Large-bore natural gas engines offer efficient power production for the purposes of generating electricity and compressing gas. Electricity generation is accomplished through mechanical coupling of the engine to a generator; "generator-set" applications for large natural gas engines commonly produce power in the 1-2 MW range. In both electricity generation and compression applications, the continuous availability of natural gas through pipeline infrastructure represents an important advantage by enabling continuous operation of the engines. In order to fully realize the continual operation advantage, natural gas engines must be durable and efficient; both requirements have been proven for reciprocating engines.

Lean burn natural gas engines offer greater efficiency than stoichiometric engines; however, NOx emissions are difficult to control in lean exhaust. Three-way catalysts commonly applied to stoichiometric engines for NOx control do not reduce NOx in lean exhaust due to the excess oxygen in the exhaust. Selective catalytic reduction with ammonia or urea-based solutions is 
capable of reducing NOx in lean exhaust; however, the requirements for ammonia or urea storage are often undesirable or impractical for many applications. Lean NOx trap (also known as NOx adsorber) catalysts have been proven to reduce NOx emissions in lean exhaust at high reduction efficiencies (>90\%). Lean NOx traps have been demonstrated on lean burn diesel and gasoline reciprocating engines and on natural gas-fired turbines. ${ }^{\mathbf{1 - 1 0}}$ In all cases, the engine fuel was used as the fuel source for reducing NOx, which represents a significant advantage in many applications.

Studies of lean NOx trap catalysis for lean natural gas reciprocating engine applications have been conducted and are reviewed here. ${ }^{11}$ A lean NOx trap catalyst was tested on a dynamometerbased engine platform, and the natural gas supplying the engine was used as the source of catalyst reductant. Results demonstrate NOx reduction efficiencies greater than 90\%; corresponding engine out NOx emissions were less than $0.1 \mathrm{~g} / \mathrm{bhp}-\mathrm{hr}$. Test results were positive, but the efficiency of the various catalytic processes involved was dependent on temperature. Based on the encouraging results, studies are now being performed to analyze the feasibility of a lean NOx trap catalyst. One area of interest is catalyst cost. Bench flow reactor tests of lean NOx trap catalysts with varying precious metal content have been performed; results are presented and discussed relative to system cost and performance issues.

\section{LEAN NOX TRAP CYCLE}

Lean NOx trap catalysts operate in a cyclic fashion. During lean operation, the catalyst adsorbs ("traps") NOx in the exhaust onto storage sites on the catalyst. The process is called "sorption" and can occur at $>90 \%$ trapping efficiencies. The catalyst is composed of alkali or alkaline earth materials that form nitrate species on the surface of the catalyst during the sorption phase. Once these nitrate species begin to saturate the catalyst, NOx trapping efficiencies begin to deteriorate, and the catalyst must be "regenerated" to renew the active sorption sites for more NOx storage. "Regeneration" occurs during net-reducing (rich) conditions and allows release of the nitrate species from the alkali/alkaline earth sites and reduction of the NOx into nitrogen. Precious metal on the catalyst assists in the release and ultimate reduction of the trapped NOx. After regeneration, the alkali/alkaline earth materials are again active for NOx trapping, and the lean-rich cyclic process begins again.

The regeneration process can occur relatively rapidly in comparison to the NOx saturation periods observed during sorption. In order to perform regeneration of the catalyst in applications where lean operation is the norm, excess fuel is introduced into the system and combusted to achieve the rich conditions. This excess fuel represents a fuel penalty. In the engine tests presented here, natural gas was injected into the exhaust system periodically and combusted over a methane oxidation catalyst to enable regeneration. As described below, a valved exhaust system was employed to control exhaust oxygen mass flow which reduced fuel requirements for the regeneration process. 


\section{ENGINE TESTING: LEAN NOX TRAP SYSTEM AND TEST PLATFORM}

Engine testing was performed on an in-line 6-cylinder 8.3-liter natural gas engine (Cummins CG-280) with a peak torque of $1153 \mathrm{Nm}$ (850 ft-lb) at $1400 \mathrm{rpm}$ and a peak power of $209 \mathrm{~kW}$ (280 hp) at $2400 \mathrm{rpm}$. The engine was turbo assisted and an intercooler was used for intake temperature control downstream of the turbo. Natural gas compressors (Copeland Model SZM22C1A-ABS-XXX) supplied the engine with fuel at 85-95 psig; a fuel meter (Micro Motion Model CMF025M009NU) allowed instantaneous measurement of fuel flow. The engine load and speed were controlled by a 600-hp dynamometer system (General Electric Model 42G61). All testing was performed at $1800 \mathrm{rpm}$ and steady-state conditions to simulate gen-set speeds. Intake air conditions were controlled to approximately $23.9^{\circ} \mathrm{C}\left(75^{\circ} \mathrm{F}\right)$ with a relative humidity of $55 \%$. Intake air flow was measured with a laminar flow element and combined with engine fuel flow measurements to estimate exhaust flow rate.

The catalyst system mounted to the engine exhaust consisted of a two-chamber system with two exhaust brake valves (US Gear) controlling the flow to both chambers (see Figure 1). The nominal exhaust pipe diameter was 4". One chamber simply consisted of an empty pipe and will be referred to as the "bypass leg". The second chamber contained the oxidation, reformer, and lean NOx trap catalysts and will be referred to as the "catalyst chamber" or "leg". Downstream of the bypass and catalyst legs, the exhaust from the two legs combined again to exit the system.

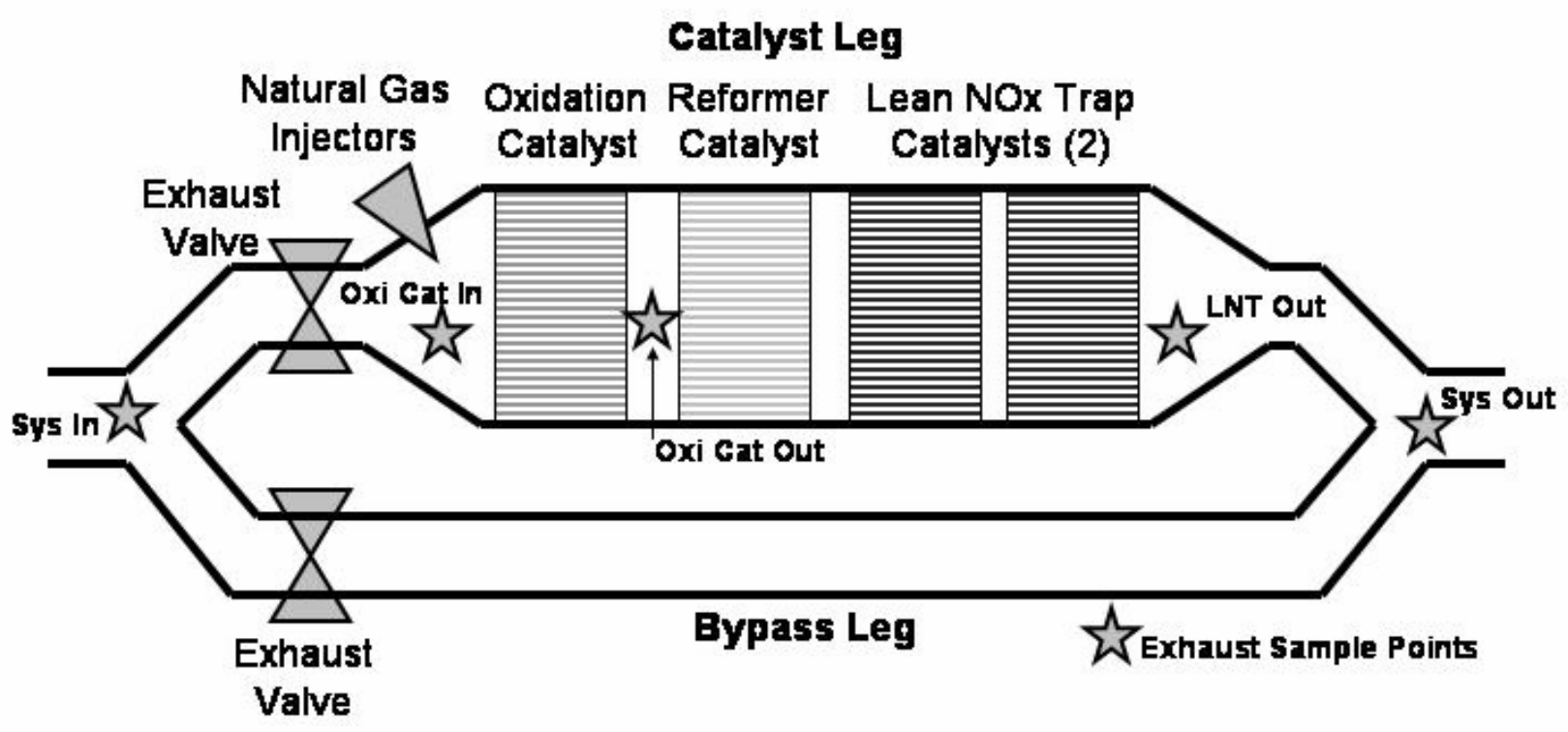

Figure 1. Lean NOx trap catalyst system.

The volumes of catalysts tested in the catalyst chamber were 7 liters, 7 liters, and 14 liters for the oxidation, reformer, and lean NOx trap catalysts, respectively. All catalysts were applied to 300 cpsi cordierite monoliths (Corning) with a 9.5” diameter and 6” length. All catalysts contained precious metal; loadings were $50 \mathrm{~g} / \mathrm{ft}^{3} \mathrm{Pd}, 60 \mathrm{~g} / \mathrm{ft}^{3} \mathrm{Pt} / \mathrm{Rh}$, and $100 \mathrm{~g} / \mathrm{ft}^{3} \mathrm{Pt}$ for the oxidation, reformer, and lean NOx trap catalysts, respectively. The order from upstream to 
downstream of the catalysts in the catalyst chamber was oxidation, reformer, and then lean NOx trap catalysts. Transition cones were used upstream and downstream of the catalyst chamber to allow exhaust transition to and from the 4" diameter exhaust pipe to the 9.5” diameter catalysts.

Testing of the catalysts was performed by closing the valve to the bypass leg and opening the valve to the catalyst chamber to let exhaust flow through the catalyst leg for the sorption part of the lean NOx trap cycle. Then, the valve to the bypass leg was opened and the valve to the catalyst chamber was closed to allow regeneration of the lean NOx trap. Thus, during regeneration, the majority of engine exhaust passed out the exhaust system untreated. It is important to note that some exhaust leakage past the closed exhaust valves occurred. The leakage rate was dependent on temperature and the pressure differential across the valve. Leakage rates were experimentally measured under a variety of engine conditions by injecting a set rate of $\mathrm{N}_{2}$ into the catalyst chamber with a mass flow controller and measuring the resulting dilution of $\mathrm{O}_{2}$ concentration. The exhaust leaking past the valves acted as both the reactant and carrier gas for the fuel injected into the catalyst chamber for catalyst regeneration. Two automotive natural gas injectors (Ford) were mounted on the inlet cone to the catalyst chamber so that fuel could be injected into the catalyst chamber during regeneration; the solenoid injectors were operated with a $75 \mathrm{~Hz} 12 \mathrm{VDC}$ signal with various duty cycles to control flow rate. The fuel supply for the injectors was the same supply for the engine, and the fuel line to the injectors was located downstream of the fuel meter. This allowed measurement of the fuel use for catalyst regeneration since all testing was performed at steady-state engine conditions. Fuel penalties on the order of $1 \%$ to $5 \%$ were measured with actual fuel penalties dependent on system geometry and catalyst volume.

The injector fueling rate and exhaust brake valves were controlled by computer via data acquisition and control software (National Instruments LabView). A second computer controlled the dynamometer system and logged data from sensors and emissions analyzers. Emissions analyzers allowed measurement of wet $\mathrm{CH}_{4}$ or total hydrocarbons (California Analytical Instruments), wet NOx as NO or NOx (California Analytical Instruments), dry $\mathrm{O}_{2}$ (Horiba), dry $\mathrm{CO}_{2}$ (Horiba), and dry CO (Horiba). Here "wet" refers to straight exhaust samples, and "dry" refers to exhaust sampled through a chiller to remove $\mathrm{H}_{2} \mathrm{O}$ from the sample stream. Also, sensors included thermocouples and pressure transducers for temperature and exhaust pressure measurements at various points in the exhaust system. Universal exhaust gas oxygen (UEGO) sensors (ECM) allowed measurement of air-to-fuel ratios in the exhaust.

Exhaust was sampled for analysis by emissions analyzers at several locations in the exhaust including positions between catalyst monoliths as described in Fig. 1. Exhaust samples were made at various points in the system as indicated by the abbreviations "Sys In", "Oxi Cat In", “Oxi Cat Out”, “LNT Out”, and "Sys Out”.

\section{ENGINE TEST RESULTS: LEAN NOX TRAP CYCLE}

A typical test of lean NOx trap performance is shown in Figure 2. The engine was operated at $1800 \mathrm{rpm}$ and 50\% load (360 ft-lb and $123 \mathrm{hp}$ ) at steady state conditions. The catalyst system was controlled with fixed periods for catalyst sorption and regeneration cycles. The sorption 
cycle was 60 seconds and the regeneration cycle was 17 seconds total with a 10 second fuel injection. The engine exhaust flow was $289 \mathrm{scfm}(8184 \mathrm{slpm})$, which correlates with a space velocity of 35,000/hr for the lean NOx trap catalysts during sorption. Eight catalyst cycles (sorption plus regeneration) are shown.

The NOx level measured immediately downstream of the catalyst varied during the catalyst cycle. Immediately after regeneration, NOx levels reached their minimum level of approximately $0.02 \mathrm{~g} / \mathrm{bhp}-\mathrm{hr}$; this represents an instantaneous NOx sorption efficiency of $98 \%$. However, as NOx storage sites fill up, the NOx emissions coming out of the lean NOx trap rise and sorption efficiency decreases. For the case shown here, NOx levels rose to approximately $0.16 \mathrm{~g} / \mathrm{bhp}-\mathrm{hr}$. The constant engine operation and constant cycle period of catalyst operation resulted in the repetitive cycle of NOx sorption and reduction shown. The combined efficiency of NOx storage and reduction is evident from the data as average NOx levels emitted from the catalyst were less than $0.1 \mathrm{~g} / \mathrm{bhp}-\mathrm{hr} \mathrm{NOx}$ and approximately 94\% lower than the engine out level.

It is important to note that during regeneration, the NOx emissions at position Sys Out are equal to the engine out emissions at position Sys In. Therefore, although the LNT catalyst is greater than $90 \%$ efficient at reducing NOx, a catalyst system with only one chamber of LNT catalyst is not capable of obtaining NOx reduction efficiencies greater than $90 \%$ continuously. An additional LNT catalyst chamber placed in the Bypass Leg (see Fig. 1) would result in a twochamber catalyst system with the capability of continuously reducing NOx from engine exhaust. In order to maximize testing flexibility, a one-chamber system was used for testing, and results will focus on the NOx reduction efficiency of the LNT catalyst, which subsequently can be used to predict the performance of different multi-chamber LNT catalyst systems.

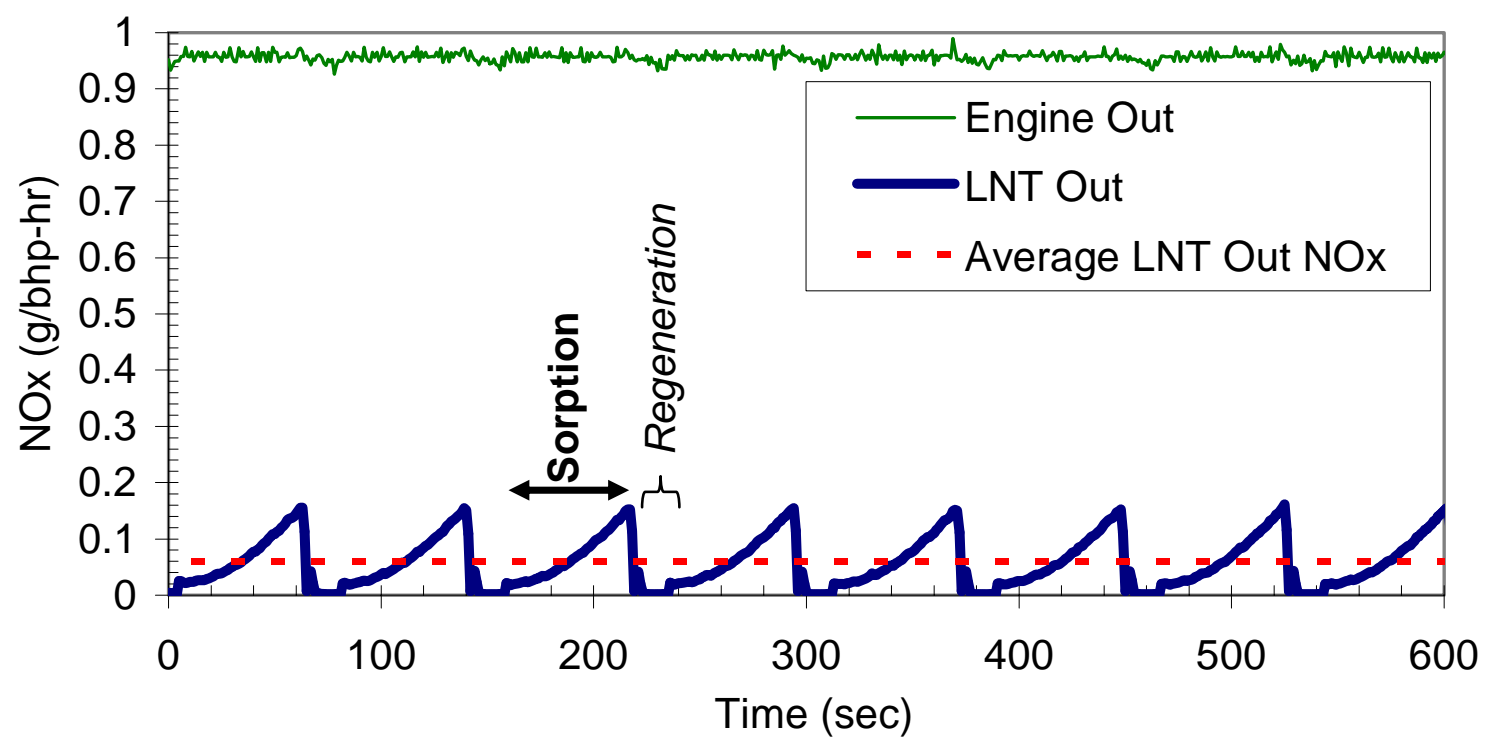

Figure 2. NOx emissions during engine testing showing the cyclic process of the lean NOx trap and overall NOx reduction efficiencies of $>90 \%$ at engine conditions of $1800 \mathrm{rpm}$ and $50 \%$ load. 


\section{TEMPERATURE EFFECTS}

Temperature affects catalytic processes significantly. Engine studies showed the effects of temperature on methane oxidation and NOx storage. Methane does not regenerate the lean NOx trap efficiently; thus, methane must be partially oxidized into $\mathrm{CO}$ and $\mathrm{H}_{2}$ products which are efficient at regeneration of the lean NOx trap. Methane oxidation as a function of temperature is shown in Figure 3. Oxidation efficiencies in lean exhaust began to rise above $400^{\circ} \mathrm{C}$ and became level above $500^{\circ} \mathrm{C}$; thus, higher exhaust temperatures are preferred for methane oxidation.
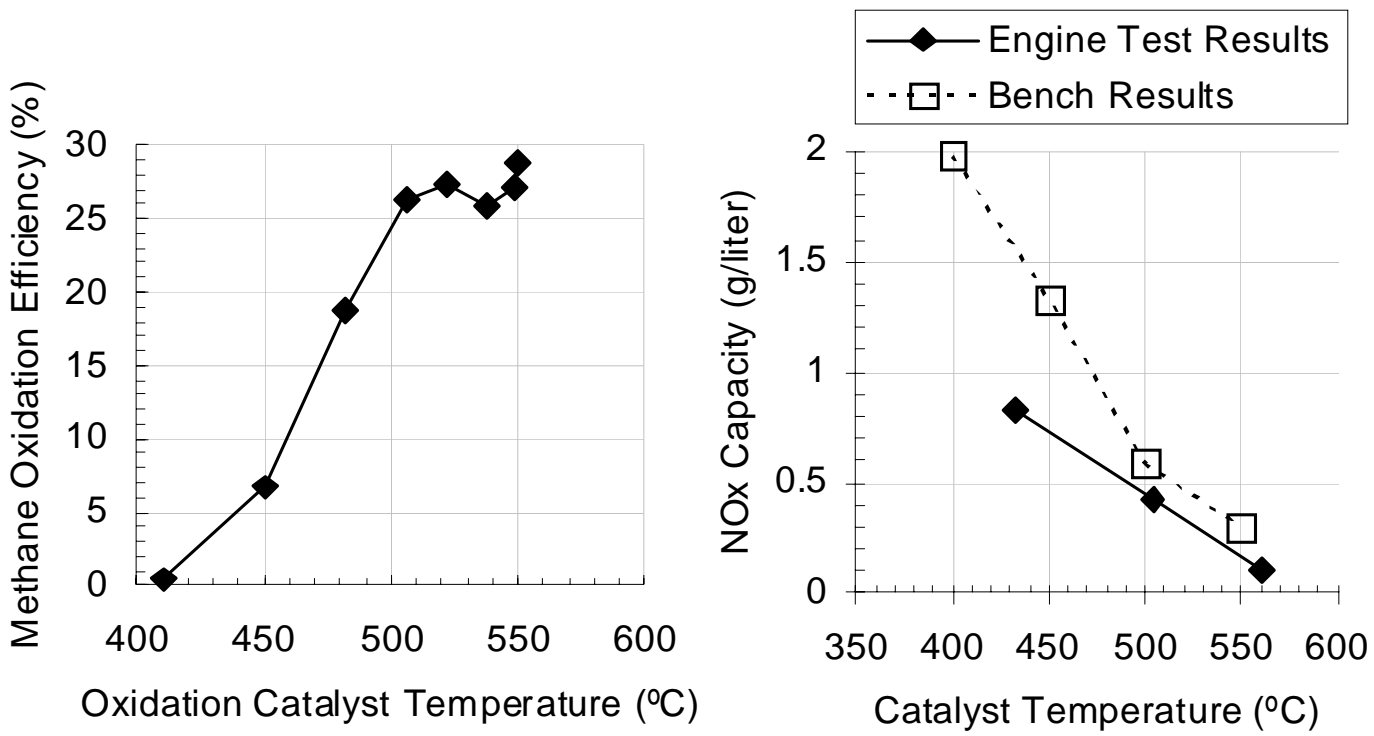

Figure 3. $\mathrm{CH}_{4}$ oxidation efficiency of the oxidation catalyst (left) and NOx storage capacity of the lean NOx trap (right) as a function of catalyst temperature.

In contrast NOx storage on the lean NOx trap deteriorates as temperatures increase. Fig. 3 shows the NOx storage capacity of the lean NOx trap in engine and bench flow reactor tests. The bench flow reactor test was conducted with simulated exhaust from bottled gases in a controlled environment. In both tests, the NOx storage capacity decreases with increasing catalyst temperature as nitrate species of the NOx storage component become less stable. The NOx storage capacity shown is measured for levels of NOx storage above $90 \%$ NOx reduction efficiencies. The capacity is effectively an indication of the cost effectiveness of the catalyst; higher NOx storage capacity indicates less catalyst volume and lower cost is required for a given engine emission rating and exhaust temperature.

\section{PRECIOUS METAL LOADING EFFECTS}

The data showing the effect of temperature on catalyst performance clearly demonstrates the need for proper thermal management in system design of lean NOx trap catalysts for natural gas engine applications. Ideally, methane oxidation should be conducted at high $\left(>500^{\circ} \mathrm{C}\right)$ 
temperatures, and NOx storage should be conducted at low $\left(<500^{\circ} \mathrm{C}\right)$ temperatures. Both capital and operating costs are dependent on the temperatures used for these catalytic processes.

In order to further probe the cost issues related to the operational temperature of the catalysts, bench flow reactor tests were conducted on lean NOx trap catalysts with three different precious metal loadings (50 g/ $\mathrm{ft}^{3} \mathrm{Pt}, 100 \mathrm{~g} / \mathrm{ft}^{3} \mathrm{Pt}$, and $200 \mathrm{~g} / \mathrm{ft}^{3} \mathrm{Pt}$ ). Recall that the precious metal loading of the lean NOx trap catalyst used for engine testing was $100 \mathrm{~g} / \mathrm{ft}^{3} \mathrm{Pt}$. Catalyst NOx capacity as a function of temperature was determined at the lower temperatures associated with higher NOx storage; results are shown in Figure 4. At low $\left(200^{\circ} \mathrm{C}\right)$ catalyst temperatures, $\mathrm{NOx}$ storage is highly dependent on Pt load; the kinetic rate of Pt-induced oxidation of $\mathrm{NO}$ to $\mathrm{NO}_{2}$ may be limiting storage in this case. However, at $400^{\circ} \mathrm{C}$, the NOx storage capacity does not appear to be a strong function of precious metal load. Therefore, operation of lean NOx trap catalysts for storage at $400^{\circ} \mathrm{C}$ enables optimal cost effectiveness. The temperature of operation for the lean NOx trap and methane oxidation catalysts plays a critical role in the cost effectiveness of a lean NOx trap catalyst system for lean natural gas engines.

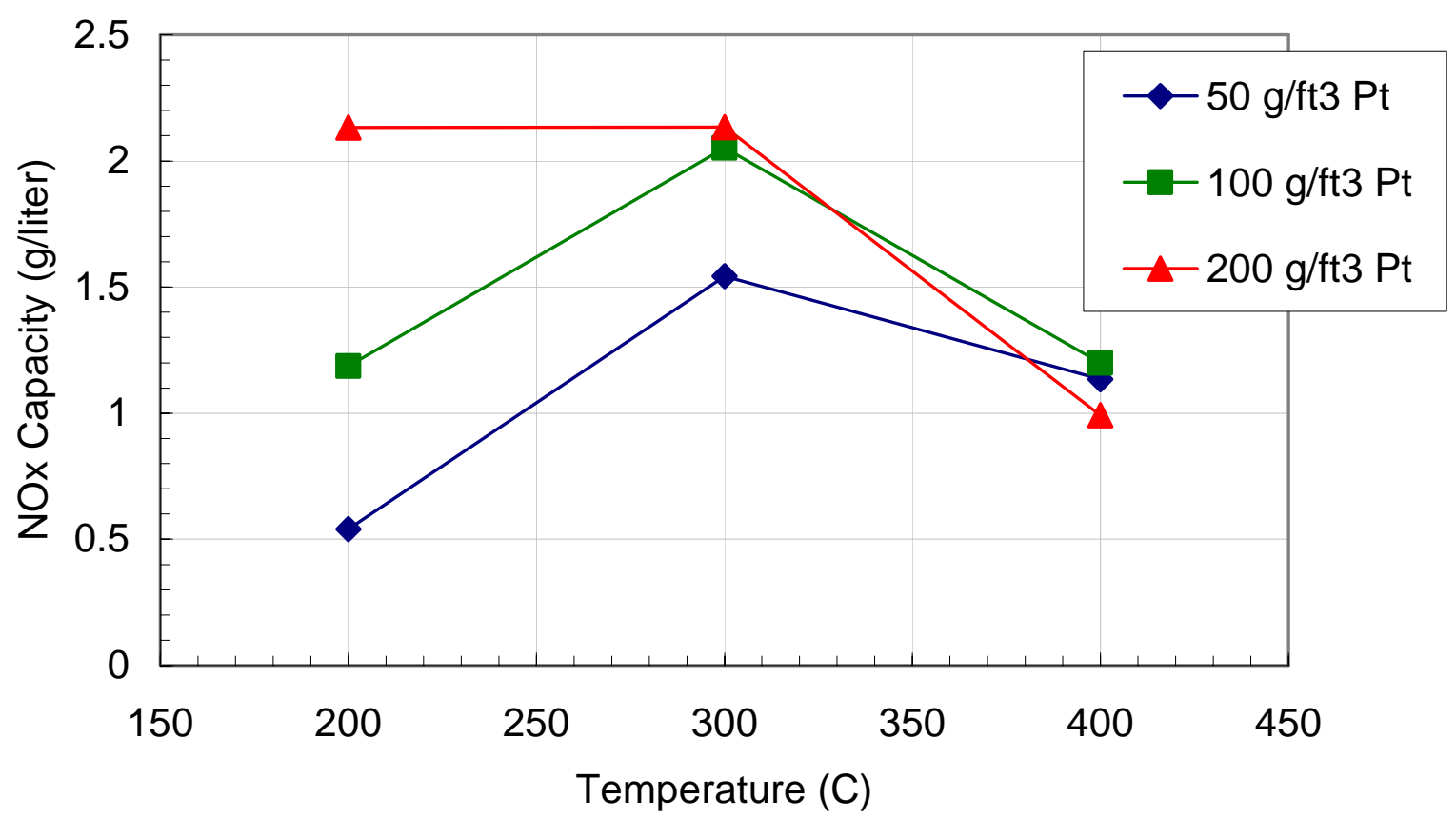

Figure 4. Lean NOx trap storage capacity as a function of catalyst temperature for three different precious metal loads.

\section{CONCLUSIONS}

Lean NOx trap catalysts can achieve high (>90\%) NOx reduction efficiencies in exhaust from lean burn natural gas engines. Furthermore, natural gas can be used as the source reductant for regeneration of the lean NOx trap. Temperature affects catalyst performance significantly. At low temperatures $\left(\sim 450^{\circ} \mathrm{C}\right)$, methane oxidation is poor and may limit NOx reduction performance. The higher temperatures $\left(\sim 550^{\circ} \mathrm{C}\right)$ more optimal for methane oxidation for lean 
NOx trap regeneration are unfortunately associated with lower NOx storage capacity of the lean NOx trap. Thus, the window of efficient operation for catalyst regeneration with methane-based fuels and efficient NOx storage capacity is limited. Thermal management of exhaust system components to operate catalysts in their optimal temperature ranges may be required to minimize system costs for commercial applications. Bench flow reactor tests indicate that maintaining lean NOx trap catalysts at temperatures of $400^{\circ} \mathrm{C}$ enables the use of lower precious metal loadings without sacrificing storage capacity which reduces catalyst cost. It is important to note that catalyst durability (an important commercial factor) was not addressed in the work.

\section{ACKNOWLEDGMENTS}

Oak Ridge National Laboratory (ORNL) would like to acknowledge EmeraChem LLC for supply of the catalysts for testing. This work is a part of the U. S. Department of Energy (DOE) Advanced Reciprocating Engine System (ARES) Program within the Office of Distributed Energy Resources. The ARES program, under the leadership of Ron Fiskum, is in cooperation with representatives from Caterpillar, Cummins, and Waukesha. The leadership of Ron Fiskum, Gordon Gerber, Axel zur Loye, and Jim Drees, is gratefully acknowledged. H. Douglas Ferguson III performed work under a subcontract with Oak Ridge Associated Universities. ORNL is managed by UT-Battelle LLC for the US Department of Energy under subcontract DEAC05-00OR22725.

\section{REFERENCES}

1. Brian H. West and C. Scott Sluder, "NOx Adsorber Performance in a Light-Duty Diesel Vehicle”, Society of Automotive Engineers Technical Series 2000-01-2912 (2000).

2. John H. Stang, David E. Koeberlein, and Michael J. Ruth, "Cummins Light Truck Diesel Engine Progress Report”, Society of Automotive Engineers Technical Series 2001-012065 (2001).

3. Joseph McDonald and Byron Bunker, "Testing of the Toyota Avensis DPNR at U. S. EPA-NVFE”, Society of Automotive Engineers Technical Series 2002-01-2877 (2002).

4. M. Kramer, J. Abthoff, F. Duvinage, N. Ruzicka, B. Krutzsch, and T. Liebscher, "Possible Exhaust Gas Aftertreatment Concepts for Passenger Car Diesel Engines with Sulphurfree Fuel”, Society of Automotive Engineers Technical Series 1999-01-1328 (1999).

5. Kinichi Iwachido, Hiroshi Tanada, Tetsuya Watanabe, Naoto Yamada, Osamu Nakayama, Hiromitsu Ando, Masao Hori, Shigeyoshi Taniguchi, Naomi Noda, and Fumio Abe, "Development of the NOx Adsorber Catalyst for Use with High-Temperature Condition", Society of Automotive Engineers Technical Series 2001-01-1298 (2001).

6. D. Gregory, R. A. Marshall, B. Eves, M. Dearth, J. Hepburn, M. Brogan, and D. Swallow, "Evolution of Lean-NOx Traps on PFI and DISI Lean Burn Vehicles", Society of Automotive Engineers Technical Series 1999-01-3498 (1999). 
7. T. H. Lake, R. G. Bending, G. P. Williams, A. J. Beaumont, A. Warburton, and J. Andersson, "Development of the Control and Aftertreatment System for a Very Low Emission G-DI Vehicle”, Society of Automotive Engineers Technical Series 1999-01-1281 (1999).

8. C. Schenk, J. McDonald, and B. Olson, "High-Efficiency NOx and PM Exhaust Emission Control for Heavy-Duty On-Highway Diesel Engines”, Society of Automotive Engineers Technical Series 2001-01-1351 (2001).

9. C. Schenk, J. McDonald, and C. Laroo, "High-Efficiency NOx and PM Exhaust Emission Control for Heavy-Duty On-Highway Diesel Engines - Part Two”, Society of Automotive Engineers Technical Series 2001-01-3619 (2001).

10. J. E. Parks II, G. J Wagner, W. S. Epling, M. W. Sanders, and L. E. Campbell, "Near-Zero NOx Control for Diesel Aftertreatment”, Society of Automotive Engineers Technical Series 1999-01-2890 (1999).

11. James E. Parks II, Aaron M. Williams, H. Douglas Ferguson III, and John M. E. Storey, "Lean NOx Trap Catalysis for NOx Reduction in Natural Gas Engine Applications", Proceedings of the ASME Internal Combustion Engine Division: 2004 Fall Technical Conference, ICEF2004-871 (2004). 